\title{
Production and specificity of mono and polyclonal antibodies against microcystins conjugated through $\mathrm{N}$ - methyldehydroalanine
}

\author{
Andrey Mikhailov ${ }^{\text {b,c }}$, Ann-Sofi Härmälä-Braskén ${ }^{\text {b,d }}$, Jussi Meriluoto ${ }^{\text {, }}$ \\ Yulia Sorokina $^{\mathrm{c}}$, Daniel Dietrich ${ }^{\mathrm{e}}$, John E. Eriksson ${ }^{\mathrm{a}, \mathrm{b}, *}$ \\ ${ }^{a}$ Department of Biology, Laboratory of Animal Physiology, University of Turku, FIN-20014, Turku, Finland \\ ${ }^{\mathrm{b}}$ Turku Centre for Biotechnology, POB 123, FIN-20521, Turku, Finland \\ ${ }^{\mathrm{c}}$ Cancer Research Center, Kashirskoe sh. 24, Moscow 115478, Russia \\ ${ }^{\mathrm{d}}$ Department of Biochemistry and Pharmacy, Abo Akademi University, POB 66, FIN-20521, Turku, Finland \\ ${ }^{\mathrm{e}}$ University of Konstanz, P.O.Box 5560-918, Konstanz, D-78434, Germany
}

\begin{abstract}
Microcystins (MCs) are a group of closely related toxic cyclic heptapeptides produced by common cyanobacteria (blue-green algae). Their toxicity is associated with specific inhibition of intracellular protein phosphatases type-1 and type-2A (PP1 and PP2A, respectively). We have developed a battery of antibodies to microcystins using chemical modification (aminoethylation) of one of its core amino acids, $N$-methyl-dehydroalanine. The developed antibodies displayed different reactivities to closely related MCs. Selected monoclonal antibodies were used for quantitative competitive ELISA assays. The analytical sensitivity of these assays was up to $1 \mathrm{ng} / \mathrm{ml}$. Comparison of the developed ELISA tests with HPLC-based measurements of MCs in laboratory and field samples showed a good correspondence between the results yielded by these two methods. The antibodies developed by this technique provide the means for developing extremely sensitive and specific analytical assays for direct measurement of toxins in cyanobacterial or water samples.
\end{abstract}

Keywords: Microcystin; Methyldehydroalanine; Aminoethylation; Antibody; Specificity; ELISA

\section{Introduction}

Microcystins (MCs) are a group of closely related cyclic heptapeptides produced by common cyanobacteria (blue-green algae), such as Microcystis, Ana-

* Corresponding author. Tel.: +358-2-333-8000; fax: + 3582-333-8036.

E-mail address: john.eriksson@mail.abo.fi (J.E. Eriksson). baena, Nostoc, and Planktothrix (Carmichael, 1997). MCs share an invariant portion of five amino acids and have, in addition, two variable amino acids as well as minor modifications of some functional groups. The common structure of MCs is cyclo(-D-Ala- $X$-D-erythro$\beta$-methyl-Asp(iso-linkage)- $Z$-Adda-D-Glu(iso-linkage)$N$-methyldehydro-Ala), where $X$ and $Z$ assign the variable amino acids and Adda is an abbreviation of 3amino-9-methoxy-10-phenyl-2,6,8-trimethyl-deca4(E)6(E)-dienoic acid (Rinehart et al., 1988). MCs are 
potent and highly specific hepatotoxins, whose toxicity is based on inhibition of type-1 (PP1) and type-2A (PP2A) protein phosphatases (MacKintosh et al., 1990). They have been reported to cause acute poisoning in humans as well as in domestic and wild animals (Carmichael, 1997). They have also been implicated as tumor promoting compounds (Falconer et al., 1996). These cyclic peptides are chemically highly stable molecules and cannot be destroyed or removed by conventional water purification methods. Hence, it is important to develop sensitive and specific methods for detection of the toxins to avoid the risks of human and animal exposure to these compounds.

For the analysis of MCs and related toxins, a number of approaches have been employed: HPLC-based analyses, protein phosphatase inhibition assays, cellular assays, and various types of immunoassays for review, see (Eriksson et al., 1994; Meriluoto et al., 2000). Chromatographic methods require highly qualified personnel as well as expensive equipments. The phosphatase inhibition assay and the cellular assays are toxicologically highly relevant, but not sensitive enough for detecting concentrations that are clearly below the level of acute toxicity. Several schemes for immunoassays of MCs have been suggested (Ueno et al., 1996; Chu et al., 1990; Nagata et al., 1995; Tsutsumi et al., 1998), but the specificity and applicability of the immunodiagnostic approach to MC analysis still requires further development. Since MCs molecules are too small to induce an active immune response by themselves, animals have usually been immunized by conjugation of MCs with high molecular weight carrier proteins, such as bovine serum albumin (BSA) or keyhole limpet hemocyanin (KLH). The coupling has been carried out with carbodiimides and the developed immune response has been tested with MCs conjugated to another carrier by the same method. During the reaction with carbodiimides MCs are attached to the carrier via the glutamic acid residue which is present in all MCs (An and Carmichael, 1994). This reaction gives high yield and MC conjugates prepared by this method have been successfully employed for production of antibodies. However, most of the monoand polyclonal antibodies prepared in this way recognize mainly the Adda residue and do not make sufficient recognition between different $\mathrm{MCs}$ (Chu et al., 1989). This situation could reflect sterical problems when the two variable amino acids are exposed to the immunocompetent cells during the development of the primary immune response. Another approach to enable conjugation of MCs to a carrier molecule is by introducing a primary amino group in the molecule. This can be carried out by aminoethylation of the $\mathrm{N}$ methyldehydroalanine residue (Moorhead et al., 1994; Härmälä-Braskén et al., 2000) presented in most MC forms. This amino acid residue reacts with the intra- cellular MC targets, such as PP1 or PP2A (Goldberg et al., 1995). This residue is located most distantly from both of the variable amino acid residues and Adda, promising active and possibly more specific immunoreactivity. The introduced primary amine can then be easily conjugated to carrier molecules.

In the current study, we tested $N$-methyldehydroalanine as a target to obtain immunogenic toxin-carrier conjugates. By using aminoethylation with subsequent conjugation to carrier proteins we synthesized immunogenic MC forms, yielding highly specific immune response in both mice and rabbits without noticeable toxicity. Polyclonal antibodies were affinity purified and tested together with a battery of selected monoclonal antibodies for direct and cross-specificity against different MCs and nodularin. Quantitative parameters of specific- and cross-binding were measured by different designs of laboratory ELISA models.

\section{Materials and Methods}

\subsection{Isolation, derivatization, and conjugation of toxins}

MC-LR and -RR, 3-desmethyl-MC-LR and -RR were purified by the method of Meriluoto et al., 1989 from extracts of Anabaena sp strain 90 (from the culture collection of Dr. Kaarina Sivonen, University of Helsinki), and MC-YR was purchased from Calbiochem (La Jolla, USA). Aminoethyl-MC-LR $\left(\mathrm{H}_{2} \mathrm{~N}-\right.$ etMC-LR) were synthesized by a modification (Härmälä-Braskén et al., 1999) of a procedure described by Moorhead and co-workers (Moorhead et al., 1994). Briefly, MC-LR was treated with 3000-fold molar excess of 2-aminoethanethiol in a carbonate-bicarbonate buffer, $\mathrm{pH} \sim 9.0$, at $+50^{\circ} \mathrm{C}$ for $30 \mathrm{~min}$. The reaction was stopped by addition of acetic acid and the product was purified from the reaction mixture on $\mathrm{C}_{18}$ BondElut $^{\mathbb{B}}$ (Varian, Harbor City, CA) cartridges with subsequent mass-spectrometric identification.

Conjugation of $\mathrm{H}_{2} \mathrm{~N}$-etMC-LR with the carrier proteins $(50 \mu \mathrm{g}$ of MC-LR per mg of BSA or soybean trypsin inhibitor [SBTI], respectively, both Sigma) was done with $2 \%$ glutaraldehyde at $\mathrm{pH} 8.7$, followed by multiple dialysis to ensure the absence of free toxin.

\subsection{Antibody production}

Polyclonal antibodies were raised in white New Zealand rabbits (both females and males) by immunization with $30 \mu \mathrm{g}$ of conjugates of the $\mathrm{H}_{2} \mathrm{~N}$-etMC-LR with SBTI. Monoclonals were produced by conventional methods, including immunization of $\mathrm{BALB} / \mathrm{c}$ mice with $10 \mu \mathrm{g} \mathrm{H}_{2} \mathrm{~N}$-etMC-LR conjugated with SBTI, 
fusion of their splenocytes with SP2/0 myeloma, selection of the hybrids and of antibody-producing clones reacting with $\mathrm{H}_{2} \mathrm{~N}$-etMC-LR covalently bound to ReactiBind $^{\mathbb{R}}$ (Pierce, Rockford, IL) 96-well plates. Finally five of 11 cloned hybridoma-producents were chosen for continued work based on their specificity and activity. The verification of murine antibody subclass was done by using a commercial kit (Pierce, Rockford, IL).

\subsection{Affinity purification}

$70 \mu \mathrm{g}$ of $\mathrm{H}_{2} \mathrm{~N}$-etMC-LR was attached to an activated $1 \mathrm{ml}$ HiTrap ${ }^{\mathbb{R}}$ column (Pharmacia) by a method described by the manufacturer. The column was used for purification of the polyclonal antibodies from pooled serum from four rabbits. Briefly, serum was diluted four times with buffer ( $25 \mathrm{mM}$ MOPS, 125 $\mathrm{mM} \mathrm{NaCl}, \mathrm{pH}$ 7.4) and cyclically passed through the column overnight at $+4^{\circ} \mathrm{C}$. The column was washed with the buffer, $1 \mathrm{M} \mathrm{NaCl}$ in the same buffer and antibodies were eluted with $100 \mathrm{mM} \mathrm{K} \mathrm{K}_{2}$. Monoclonal antibodies were purified on a ProteinG HiTrap ${ }^{\mathbb{R}}$ column (Pharmacia) by a method recommended by the manufacturer.

\subsection{ELISA assays}

For competition ELISA tests, $1 \mu \mathrm{g}$ of $\mathrm{H}_{2} \mathrm{~N}$-etMCLR was covalently bound to ReactiBind ${ }^{\mathbb{R}}$ plates or 50 $\mu \mathrm{g}$ of purified monoclonal antibodies were adsorbed to each of polyvinylchloride plates. $\mathrm{H}_{2} \mathrm{~N}$-etMC-LR and purified monoclonal antibodies were conjugated in equimolar proportions with $\mathrm{EZ}^{\mathbb{R}}$-activated soybean peroxidase (Pierce Rockford, IL) by the method recommended by the manufacturer, with subsequent purification on PD-10 gel filtration columns (Pharmacia). The competition assay was performed in one step by incubating serial dilutions of free MC with antibodyperoxidase conjugate on $\mathrm{H}_{2} \mathrm{~N}$-etMC-LR-coated plates or with $\mathrm{H}_{2} \mathrm{~N}$-etMC-LR-peroxidase conjugate on antibody-coated plates. Plates were carefully washed and the optical densities (OD) of the substrate (tetramethylbenzidine, Sigma, St. Louise, MO) reaction was measured at dual wavelength $620-492 \mathrm{~nm}$.

\subsection{Toxin analysis from cyanobacterial cultures and natural field samples}

Field samples of cyanobacteria collected from eutrophic lakes were freeze-thawed and ultrasonicated. Dilutions of the sonicated suspensions were used for ELISA experiments. Parallel samples were analyzed by HPLC as follows: $10 \mathrm{ml}$ methanol was added to 100 $\mathrm{ml}$ aliquots of the undiluted sonicated suspensions and the samples were concentrated on activated $\mathrm{C}_{18}$ Bond
Elut ${ }^{\circledR}$ solid-phase extraction cartridges $(500 \mathrm{mg}$; Varian, Palo Alto, CA). The cartridges were eluted with $10 \mathrm{ml}$ methanol, which was dried under vacuum at $40^{\circ} \mathrm{C}$. The samples were then redissolved in $0.5 \mathrm{ml}$ methanol, centrifuged $(10000 \mathrm{~g}, 10 \mathrm{~min})$ and analyzed by HPLC. Methanolic extracts of freeze-thawed laboratory-grown Microcystis PCC7820 and Anabaena 90 were run without concentration. The MCs in the extracts of Microcystis and Anabaena (LR, 3-desmethylated LR, LW, LF, RR, 3-desmethylated RR) had been previously characterized by their UV spectra, amino acid analysis and mass spectrometry. The known MCs were used for the retention time-based identification of MCs in the field samples. On-line UV spectra of the separated peaks in the field samples, although often disturbed by coeluting compounds, gave additional verification about the peak identities. $10 \mu \mathrm{l}$ aliquots of the field and laboratory samples were separated on a Merck (Darmstadt, Germany) Nucleosil $1005 \mathrm{C}_{18}$ column $(250 \mathrm{~mm} \times 4 \mathrm{~mm}$ i.d. $)$. The mobile phase consisted of (A) acetonitrile:0.0135 M ammonium acetate (27:73) and (B) acetonitrile:0.0493 M ammonium acetate (80:20); linear gradient 0 min $100 \%$ A, $12 \min 100 \%$ A, $24 \min 75 \%$ A, $28 \min 75 \%$ A, 30 min $100 \% \mathrm{~A}$; flow rate $1 \mathrm{ml} / \mathrm{min}$; column temperature $40^{\circ} \mathrm{C}$. Detection was performed at $200-300 \mathrm{~nm}$ using an L-7450A diode-array detector (Merck-Hitachi, Darmstadt, Germany).

\section{Results}

The specific activity of the antibodies was tested in direct ELISA tests with either $\mathrm{H}_{2} \mathrm{~N}$-etMC-LR covalently attached to activated polystyrol plates (ReactiBind $^{\mathbb{R}}$, Pierce) or as conjugated to BSA with the conjugate adsorbed on polyvinylchloride 96-well plates (Falcon-BD, Franklin Lakes, NJ). Minimal working dilutions of sera were 1:2000-1:60000. These reactivities were three to five orders of magnitude higher than those obtained with unspecific reaction of preimmune sera collected from the same animals (data not shown). Monoclonal antibodies reacted at lower minimal dilutions (1:200-1:4000) but in a highly specific fashion when compared to a non-MC binding monoclonal antibody (we used anti-vimentin antibodies as a control), which gave a positive signal only at 1:40 or lower dilutions (data not shown). Neither the monoclonal antibodies nor the affinity-purified polyclonal antibodies reacted with free BSA, Tris-blocked ReactiBind $^{\mathbb{R}}$ plates, or free SBTI adsorbed on polyvinylchloride plates (data not shown). Mouse antibody subclass verification showed that all six hybridomas selected for further work were secreting $\operatorname{IgG}_{1}$ antibodies with light chain $\kappa$ (data not shown). 


\subsection{Competitional ELISA}

To ensure the specific and reversible binding of the mono- and polyclonal antibodies, we performed competitional ELISA-testing. We tested two ELISA model designs, with the antigen (design A) or the antibodies (design B) attached to the surface. Dilutions of MCLR competed for antibodies conjugated to peroxidase with MC-LR attached to the surface (design A) or for adsorbed antibodies with MC-LR conjugated with peroxidase (design $\mathrm{B}$ ) in a concentration range starting at $1 \mathrm{ng} / \mathrm{ml}$. The model with $\mathrm{H}_{2} \mathrm{~N}$-etMC-LR covalently bound to ReactiBind shows a sharper inhibition profile, while the one with adsorbed antibodies has a wider range of inhibition (Fig. 1).

\subsection{Cross-competition}

To estimate the specificity of our antibodies, we checked the ability of four MCs, a synthetic derivate of MC-LR, and nodularin, a closely related toxin, to compete MC-LR in the above described competitional ELISA model (Table 1,Fig. 2).

The specificity of different monoclonal antibodies varied from practically equal reactivity between different MCs and MC-LR to 16 times less active reaction with MC-YR. Nodularin also had noticeable crossreactivity with all the tested antibodies, although much less than MCs - from 2 to about 1000 times less. Free $\mathrm{H}_{2} \mathrm{~N}$-etMC-LR competes for antibodies and is up to nine times stronger than MC-LR. This result is to be expected, since this toxin derivative was used for immunogen preparation. Affinity purified polyclonal antibodies showed approximately equal reactivity to all the MCs and nodularin. By the criteria of lower background signal and higher signal/noise ratio (data not shown) we selected monoclonal antibody produced by clone M1E for presented work in quantitative ELISA measurements of MCs in cultured and field samples.

\subsection{Antibody test with field samples}

To establish the reliability of the model test systems, we measured $\mathrm{MC}$ concentration in two ultrasonicated lake water samples from Lake Omenajärvi and Lake Kirkkojärvi (South-Western Finland) as well as in two cyanobacterial culture samples. The concentrations were measured by using standard curve for MC-LR obtained from the analysis model with monoclonal antibody clone M1E conjugated with peroxidase. The concentration of MCs in the same samples was analyzed chromatographically by HPLC (Fig. 3). Field samples from heavily eutrophicated lakes are often problematic in regard to HPLC identification of MCs. Small MC peaks coeluting with other substances often fail to give useful UV spectra for the spectral identification of MCs. The estimated concentrations and identified compositions of the MCs in cultured as well as environmental samples are shown in Table 2.

Although, the positive identification of the whole spectrum of possible MCs in environmental samples is an almost impossible task, both methods show satisfactory correlation between the results. The variation between samples in the different ratios of MCs as measured by HPLC and ELISA, could reflect variations in antibody reactivity against the different MCs as well as the possible presence of unidentified MCs in the environmental samples.

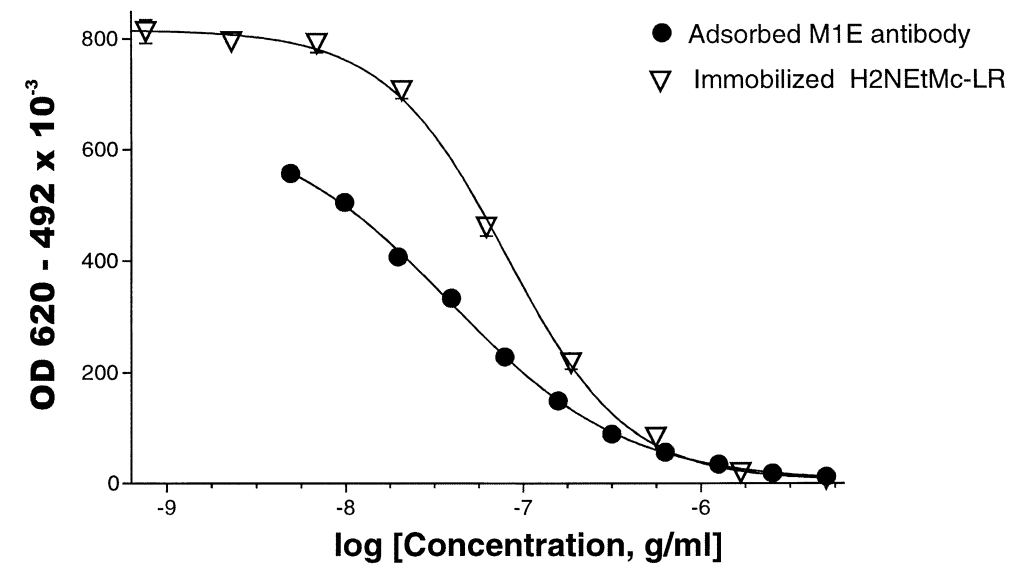

Fig. 1. Comparison of two ELISA models. Competition between the MC-LR (in standard and/or sample) and adsorbed $\mathrm{H}_{2} \mathrm{~N}-$ etMC-LR for monoclonal antibody conjugated with peroxidase (filled circles). Competition between free MC-LR (in standard and/ or sample) and conjugate of $\mathrm{H}_{2} \mathrm{~N}$-etMC-LR with $\mathrm{EZ}^{\mathbb{R}}$-activated soybean peroxidase for adsorbed monoclonal antibody (open triangels). 
Table 1

Cross-reactivity of designed antibodies with closely related MCs and nodularin. The ratio of immunoreactivity obtained with the tested antigen versus the reactivity of MC-LR $(=1)$ in a competitional immunoassay with adsorbed $\mathrm{H}_{2} \mathrm{~N}$-etMC-LR giving $50 \%$ inhibition of maximal binding (smaller value $=$ higher reactivity)

\begin{tabular}{lllllll}
\hline Antigen/Abs & AffiPoly & M1B & M1C & M1D & M1E & M2.1 \\
\hline MC-RR & 1.1 & 1.3 & 1.0 & 4.5 & 5.0 & N/D \\
dm-MC-LR & 1.0 & 1.0 & 0.9 & 1.9 & 1.0 & 1.4 \\
dm-MC-RR & 1.0 & 1.1 & 1.0 & 4.0 & 3.9 & 2.8 \\
Free $\mathrm{H}_{2}$ N-etMC-LR & 0.9 & 0.15 & N/D & 0.18 & 0.11 & 0.19 \\
MC-YR & 2.0 & 3.95 & 11 & 16 & 4.0 & 5.1 \\
Nodularin & 1.5 & N/D & 2.0 & 970 & N/D & 9.7 \\
\hline
\end{tabular}

Table 2

The correspondence between the quantitative measurements of MC in the extracts of different cyanobacterial samples. Quantification observed in ELISA assay versus that obtained in an HPLC-based chromatographical assay

\begin{tabular}{lll}
\hline Name of sample & $\begin{array}{l}\text { MC composition and concentrations estimated by } \\
\text { HPLC }\end{array}$ & $\begin{array}{l}\text { MC concentrations estimated in ELISA with M1E } \\
\text { antibody }\end{array}$ \\
\hline $\begin{array}{l}\text { Microcystis } \\
\text { aeruginosa }\end{array}$ & MC-LR $-54 \mu \mathrm{g} / \mathrm{ml}$ & $39 \mu \mathrm{g} / \mathrm{ml}$ \\
PCC 7820 & MC-LW $-22 \mu \mathrm{g} / \mathrm{ml}$ & \\
Anabaena 90 & MC-LF $-20 \mu \mathrm{g} / \mathrm{ml}$ & $9 \mu \mathrm{g} / \mathrm{ml}$ \\
& MC-LR $-5.4 \mu \mathrm{g} / \mathrm{ml}$ & \\
& 3-dm-MC-LR $-0.9 \mu \mathrm{g} / \mathrm{ml}$ & \\
& 3-dm-MC-RR $-1.9 \mu \mathrm{g} / \mathrm{ml}$ & $39 \mathrm{ng} / \mathrm{ml}$ \\
Kirkkojärvi & MC-RR $-6.7 \mu \mathrm{g} / \mathrm{ml}$ & $15 \mathrm{ng} / \mathrm{ml}$ \\
Omenajärvi & MC-LR $-75 \mathrm{ng} / \mathrm{ml}$ & \\
\hline
\end{tabular}

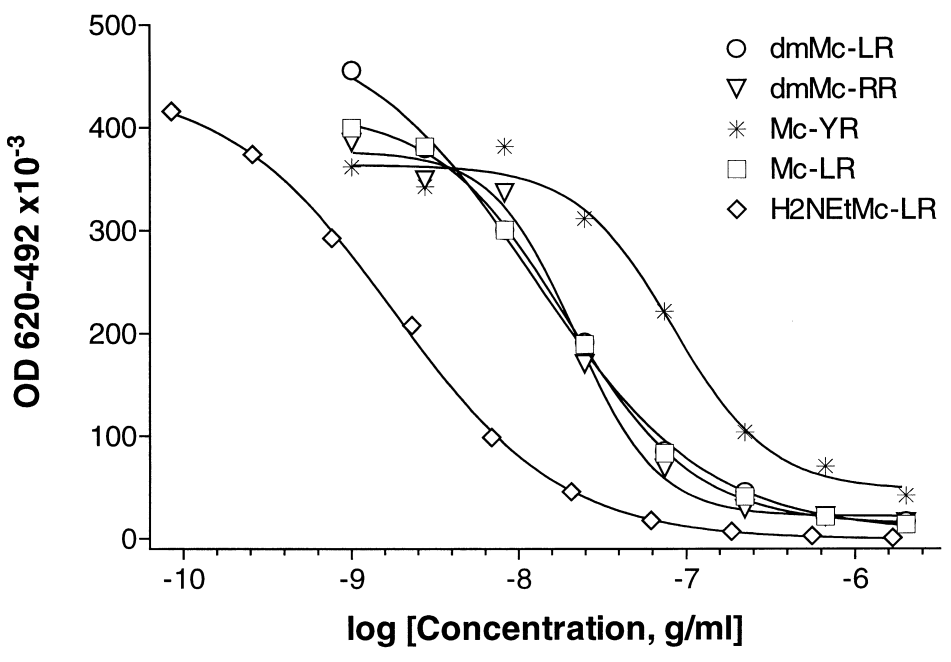

Fig. 2. Different MCs compete with adsorbed $\mathrm{H}_{2} \mathrm{~N}$-etMC-LR with different affinity. Known concentrations of different MCs were used in the competitive ELISA model with adsorbed $\mathrm{H}_{2} \mathrm{~N}$-etMC-LR. The figure shows examples of free MCs competing for the binding of different monoclonal antibodies to the adsorbed $\mathrm{H}_{2} \mathrm{~N}$-etMC-LR. The competition curves of the M1B monoclonal antibodies is shown (others listed in Table 1 but not shown). 


\section{Discussion}

Using the method of MC conjugation to carriers via aminoethylated dehydro-alanine, we produced a battery of monoclonal antibodies with a different degree of cross-reactivity between immunogen (MC-LR) and closely related toxins. The antibodies developed in this way showed a higher degree of specificity to the MCLR and its derivates as compared to other MCs and nodularin than previously reported antibodies (Nagata et al., 1995). However, there was still a tendency of significant cross-reaction between all of the MC subtypes and nodularin. This cross-reactivity could be explained by strong immunogenic properties of the epitope containing the Adda residue as compared to the rest of the $\mathrm{MC}$ molecule. In support of this assumption, it has been reported that MC derivatives, in which Adda is destroyed by ozonolysis, are not immunoreactive (Chu et al., 1989). Furthermore, three-dimensional NMRbased structure analysis of MCs (Trogen et al., 1996) and nodularin(Annila et al., 1996) showed that Adda is the best-exposed part of both peptides. Adda will also be one of the best exposed parts of the MC molecule in conjugates produced both by conjugation through carboxy-groups or by conjugation through an introduced amino group. However, the conjugation via $N$-methyldehydroalanine is likely to help exposing both of the variable amino acids better than carbodiimide conjugation.

The detection limit of our ELISA model systems was sufficient for direct measurement of total MCs in real samples as well as for quantitative cross-reaction estimations. The sensitivity was estimated to be approximately $5 \mathrm{ng} / \mathrm{ml}$ when using monoclonal M1E, and MC-LR as standard, in the ELISA model with immobilized $\mathrm{H}_{2} \mathrm{~N}$-etMC-LR. The sensitivity of the ELISA model, where $\mathrm{H}_{2} \mathrm{~N}$-etMC-LR was used as a standard, was proportionally higher that in the ELISA models based on other MC and nodularin as standards. Other monoclonal antibodies gave similar values of analytical sensitivity in the range of $1-10 \mathrm{ng} / \mathrm{ml}$. The highest sensitivity was seen with the monoclonal
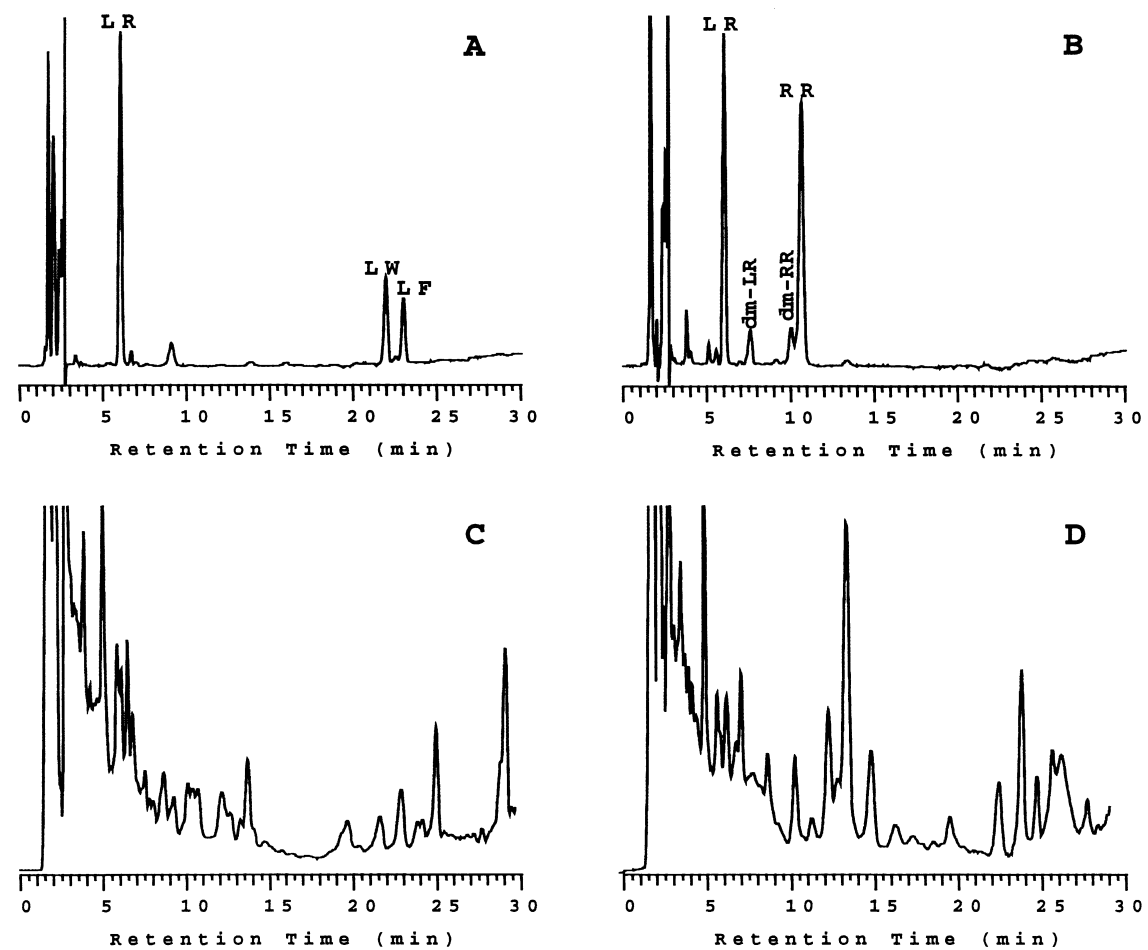

Fig. 3. HPLC determination and identification of MCs from cyanobacterial culture and lake samples. UV absorbance at $238 \mathrm{~nm}$ is shown in HPLC chromatograms of (A) Microcystis extracts containing MCs-LR, -LW and -LF, (B) Anabaena extracts containing MCs-LR, -RR and their 3-desmethylated analogues, (C) Lake Kirkkojärvi sample and (D) Lake Omenajärvi sample. HPLC conditions were as described in the methods sections. As no good UV spectra could be obtained from the field samples (C) and (D), due to low peak heights and interfering coeluting compounds, tentative MC identification was based on the retention times. Both sample (C) and (D) had a peak coeluting with MC-LR in the standards (A) and (B). No other peaks had identical retention times with the MC peaks in the standards. 
M1B when $\mathrm{H}_{2} \mathrm{~N}$-etMC-LR was used as a standard (the whole data set is not shown).

Although both ELISA- and HPLC-based determination of MCs gave satisfactory agreement between the obtained results, the values determined by ELISA were usually lower than those determined by HPLC. It could be a reflection of a somewhat higher specificity in the ELISA method, as overlapping peaks in the chromatograms may affect quantification.

Since ELISA based on different monoclonals give predictably different data curves for different MCs, it is possible to calculate the ratio of different MCs in a sample by simultaneous ELISA measurements with the various antibodies developed. We are continuing to test the applicability of the described antibodies for toxin analysis in cyanobacterial and water samples as well as in animal tissues. Furthermore, these antibodies are being assessed for their ability to reveal possible in vivo binding targets of $\mathrm{MCs}$ other than $\mathrm{PP} 1$ and PP2A.

\section{Acknowledgements}

This work was supported by the European Union (INCO Copernicus program), by the Academy of Finland (grants 29641 and 30602), by the Victoria Foundation and Maj and Tor Nessling Foundation, and by Magnus Ehrnrooth Foundation.

\section{References}

An, J.-S., Carmichael, W.W., 1994. Use of a colorimetric protein phosphatase inhibition assay and enzyme linked immunosorbent assay for the study of microcystins and nodularins. Toxicon 32, 1495-1507.

Annila, A., Lehtimäki, J., Mattila, K., Eriksson, J.E., Sivonen, K., Rantala, T.T., Drakenberg, T., 1996. Solution structure of nodularin. An inhibitor of serine/ threonine-specific protein phosphatases. J. Biol. Chem. 271, 16695-16702.

Carmichael, W.W., 1997. The cyanotoxins. Adv. Bot. Res. 27, 211-256

Chu, F.S., Huang, X., Wei, R.D., Carmicael, W.W., 1989. Production and characterization of antibodies against microcystins. Appl. Environ. Microbiol. 55, 1928-1933.

Chu, F.S., Huang, X., Wei, R.D., 1990. Enzyme-linked immunosorbent assay for microcystins in blue-green algal blooms. J. Assoc. Offic. Anal. Chem. 73, 451-456.

Eriksson, J.E., Toivola, D.M., Reinikainen, M., Råbergh, C.M.I., Meriluoto, J.A.O., 1994. Testing of toxicity in cyanobacteria by cellular assays. In: Codd, G.A., Jefferies, T.M., Keevil, C.W., Potter, E. (Eds.), Detection Methods for Cyanobacterial Toxins. The Royal Society of Chemistry, Cambridge, pp. 75-84.

Falconer, I.R., 1991. Tumor promotion and liver injury caused by oral consumption of cyanobacteria. Environ. Toxicol. Water Qual. 6, 177-184.

Goldberg, J., Huang, H., Kwon, Y., Greengard, P., Nairn, A.G., Kuriyan, J., 1995. Three-dimentional structure of the catalytic subunit of protein serine/threonine phosphatase-1. Nature 376, 745-753.

Härmälä-Brasken, A.-S., Mikhailov A., Murata, K., Brautigan, D.L., Eriksson J.E., 2000. Microcystin-LR affinity binding reveals in vivo multisite phosphorylation of protein phosphatase $2 \mathrm{~A}$ and its association with multiple phopsphoproteins, submitted.

MacKintosh, C., Beattie, K.A., Klumpp, S., Cohem, P., Codd, G.A., 1990. Cyanobacterial microcystin-LR is a potent and specific inhibitor of protein phosphatases 1 and $2 \mathrm{~A}$ from both mammals and higher plants. FEBS Letters. 264, 187-192.

Meriluoto, J., Lawton, L., Harada, K.-I., 2000. Isolation and detection of microcystins and nodularins, cyanobacterial peptide hepatotoxins. In: Holst, O. (Ed.), Bacterial Toxins: Methods and Protocols. Humana Press, Totowa, NJ (in press).

Meriluoto, J., Sandström, A., Eriksson, J.E., Remaud, G., Craig, A.G., Chattopadhyaya, J., 1989. Structure and toxicity of a peptide hepatotoxin from the cyanobacterium Oscillatoria agardhii. Toxicon 27, 1021-1034.

Moorhead, G., MacKintosh, R.W., Morrice, N., Gallagher, T., MacKintosh, C., 1994. Purification of type-1 protein (serine/threonine) phosphatases by microcystin-Sepharose affinity chromatography. FEBS Lett. 356, 46-50.

Nagata, S., Suotome, H., Tsutsumi, T., Hasegawa, A., Sekijima, M., Sugamata, M., Harada, K.-I., Suganuma, M., Ueno, Y., 1995. Novel monoclonal antibodies against microcystin and their protective activity for hepatotoxicity. Nat. Tox. 3, 78-86.

Rinehart, K.L., Harada, K.-i., Namikoshi, M., Chen, C., Harvis, C.A., Munro, M.H.G., Blunt, J.W., Mulligan, P.E., Beasley, V.R., Dahlem, A.M., Carmichael, W.W., 1988. Nodularin, microcystin and the configuration of Adda. J. Am. Chem. Soc. 110, 8557-8558.

Tsutsumi, T., Nagata, S., Yoshida, F., Ueno, Y., 1998. Development of sandwich immunoassay for microcystins, a natural contaminant in environmental water: an assay based on anti-immune complex antibodies. Jpn. J. Toxicol. Environ. Health. 44, 25.

Trogen, G.-B., Annila, A., Eriksson, J., Kontteli, M., Meriluoto, J., Sethson, I., Zdunek, J., Edlund, U., 1996. Conformational studies of microcystin-LR using NMR spectroscopy and molecular dynamics calculations. Biochemistry 35, 3197-3205.

Ueno, Y., Nagata, S., Tsutsumi, T., Hasegawa, A., Yoshida, F., Suttajit, M., Mebs, D., Putsch, M., Vasconcelos, V., 1996. Survey of microcystin in environmental water by a highly sensitive immunoassay based on monoclonal antibody. Nat. Tox. 4, 271-276. 